Insight, part of a Special Feature on Landscape Scenarios and Multifunctionality - Making Land Use Assessment Operational

\title{
How Personal Judgment Influences Scenario Development: an Example for Future Rural Development in Europe
}

\author{
Marc J. Metzger $^{1,2}$, Mark D.A. Rounsevell ${ }^{3}$, Harm A.R.M. Van den Heiligenberg ${ }^{4,5}$, Marta Pérez-Soba ${ }^{2}$, and
} Paul Soto Hardiman 6

\begin{abstract}
Scenarios of alternative plausible futures have been used extensively to explore the potential effects of socioeconomic and environmental change. The ultimate objective of any explorative scenario exercise is to assess the variation in possible futures to provide insights into the range of potential outcomes. These results provide stakeholders with guidance for policy development, planning, and management. We explore how personal judgment can influence scenario development. Scenarios for the future of European rural regions are used to explore alternative outcomes under a public interventionist future and a market liberalization oriented future. A transparent qualitative framework is used to identify differences in outcomes based on personal judgment. Results show that, for both scenarios, there are plausible mechanisms that can lead to similar positive or negative outcomes. Choosing a single process per scenario, based on personal judgment and interpretation, can therefore greatly influence scenario outcomes and limit the range of uncertainty that is covered by the scenarios. The exercise shows the importance of making these judgments explicit in scenario development, especially when exploring broad consequences of alternative policy directions that may be based in political worldviews.
\end{abstract}

Key Words: Common Agricultural Policy reform; explorative scenarios; personal judgment; rural development; uncertainty

\section{INTRODUCTION}

The main socioeconomic drivers of environmental change are global in scope and are inherently unpredictable (MA 2005, IPCC 2007). Scenarios that provide alternative images of how the future may unfold can act as an integration tool in assessing the effects of future environmental and social change (Zurek and Henrichs 2007, Rounsevell and Metzger 2010). Although we cannot attach a probability of occurrence to any given scenario, scenarios help to stimulate open discussion in the policy arena about potential futures (Van der Heijden 2005). Over the last decade, a large number of studies have developed scenarios to explore potential future changes at different geographical scales. Rashkin (2005) gives an overview of recent global exercises, including the climate change scenarios of the Intergovernmental Panel on
Climate Change (IPCC) Special Report on Emissions Scenarios (Nakicenovic et al. 2000) and the Millennium Ecosystem Assessment (MA 2005). At the subglobal scale, many scenarios studies have been conducted for the European Union (EU). We compare the objectives and characteristics of some of these scenarios (Table 1).

Despite the increased use of scenarios in global change science, the associated terminology remains loosely defined. We have therefore included a list of definitions of the most important terminology used (Table 2).

Although scenario studies have been used for different objectives, there is considerable overlap in the conceptual frameworks adopted to structure these scenarios (i.e., scenario logic) and the models applied to quantify the scenario outcomes. For

${ }^{1}$ Centre for the Study of Environmental Change and Sustainability (CECS), University of Edinburgh, ${ }^{2}$ Alterra Wageningen University and Research Centre, ${ }^{3}$ Centre for the study of Environmental Change and Sustainability (CECS), University of Edinburgh, ${ }^{4}$ Netherlands Environmental Assessment Agency

(PBL), ${ }^{5}$ Province of Utrecht, ${ }^{6}$ Grupo Alba 
Table 1. Overview of a range of existing scenario studies for the European Union.

\begin{tabular}{|c|c|c|c|c|c|}
\hline Name Objective & Extent & $\begin{array}{l}\text { Temporal } \\
\text { scale }\end{array}$ & $\begin{array}{l}\text { Spatial } \\
\text { resolution }\end{array}$ & $\begin{array}{l}\text { Quantified } \\
\text { variables }\end{array}$ & Scenario names \\
\hline
\end{tabular}

$\operatorname{ATEAM}^{\dagger}$ (Rounsevell et al. 2006)

\begin{tabular}{|c|c|c|c|c|c|}
\hline $\begin{array}{l}\text { Land use scenarios } \\
\text { for models to assess } \\
\text { effects on ecosystem } \\
\text { services }\end{array}$ & $\begin{array}{l}\text { EU15 } \\
\text { Norway } \\
\text { Switzerl- } \\
\text { and }\end{array}$ & $\begin{array}{l}2020 \\
2050 \\
2080\end{array}$ & $\begin{array}{l}\% \text { cover in } \\
10 \text { arc minute } \\
\text { grid cell }\end{array}$ & $\begin{array}{l}\text { Land use: urban, } \\
\text { cropland, } \\
\text { grassland, } \\
\text { permanent crops, } \\
\text { bio fuels, } \\
\text { abandoned land }\end{array}$ & $\begin{array}{l}\text { Global Economic - A1 } \\
\text { Regional Economic - A2 } \\
\text { Global Environmental - B1 } \\
\text { Regional Environmental - B2 }\end{array}$ \\
\hline$e^{\ddagger}($ EEA 2007) & & & & & \\
\hline $\begin{array}{l}\text { Inspire and inform } \\
\text { discussion }\end{array}$ & $\begin{array}{l}\text { EU25, } \\
\text { Norway, } \\
\text { Switzerl- } \\
\text { and }\end{array}$ & $\begin{array}{l}\text { Annual } \\
\text { time } \\
\text { steps } \\
2005-2035\end{array}$ & $\begin{array}{l}\% \text { cover in } \\
10 \text { arc minute } \\
\text { grid cell }\end{array}$ & $\begin{array}{l}\text { Land use: urban, } \\
\text { cropland, } \\
\text { grassland, } \\
\text { permanent crops, } \\
\text { bio fuels, } \\
\text { abandoned land }\end{array}$ & $\begin{array}{l}\text { Great Escape - Europe of Contrasts } \\
\text { Evolved Society - Europe of } \\
\text { Harmony } \\
\text { Clustered Network - Europe of } \\
\text { Structure } \\
\text { Lettuce Surprise U - Europe of } \\
\text { Innovation } \\
\text { Big Crisis - Europe of Cohesion }\end{array}$ \\
\hline
\end{tabular}

$\operatorname{ALARM}^{\S}$ (Settele et al. 2005; I. Reginster, M. Rounsevell, F. Riguelle, T. R. Carter, S. Fronzek, I. Oman, J. H. Spangenberg, A. Stocker, A. Bondeau, T. Hickler unpublished manuscript)

\begin{tabular}{|c|c|c|c|c|c|}
\hline $\begin{array}{l}\text { Land use scenarios } \\
\text { for models to assess } \\
\text { effects on } \\
\text { biodiversity }\end{array}$ & $\begin{array}{l}\text { EU25, } \\
\text { Norway, } \\
\text { Switzerl- } \\
\text { and }\end{array}$ & $\begin{array}{l}\text { Annual } \\
\text { time } \\
\text { steps } \\
2006-2080\end{array}$ & $\begin{array}{l}\% \text { cover in } \\
10 \text { arc minute } \\
\text { grid cell }\end{array}$ & $\begin{array}{l}\text { Land use: urban, } \\
\text { cropland, } \\
\text { grassland, } \\
\text { permanent crops, } \\
\text { bio fuels, } \\
\text { abandoned land }\end{array}$ & $\begin{array}{l}\text { Growth applied strategy (GRAS) } \\
\text { Business as might be usual } \\
\text { (BAMBU) } \\
\text { Sustainable European development } \\
\text { goal (SEDGE) } \\
\text { Shock in energy price level } \\
\text { (BAMBU-SEL) } \\
\text { Cooling under thermohaline collapse } \\
\text { (GRAS-CUT) } \\
\text { Contagious natural epidemic } \\
\text { (BAMBU-CANE) }\end{array}$ \\
\hline
\end{tabular}

SENSOR' (Kuhlman 2008, Helming et al. 2008)

Policy scenarios to $\quad$ EU27 $2025 \quad$ NUTS2/3 $3^{\dagger \dagger} \quad 86$ social and illustrate and quantify consequences of specific European policies on land use and a number of indicators socioeconomic environmental data, $1 \mathrm{~km}$ indicators and land use land use functions Land use: 13 classes
Reference: Reference growth, High growth, Low growth Policy: Bioenergy, EU Financial Reform, Biodiversity, Forest management, Transport

EURURALIS $^{\text {II }}$ (WUR/MNP 2008) 
Tool for the support of policy discussions on long term changes and policy challenges in the rural areas of Europe
EU27

$\begin{array}{cl}\text { Annual } & \text { NUTS2/3 } \\ \text { time } & \text { socioeconomic } \\ \text { steps } & \text { data, } 1 \mathrm{~km} \\ \text { 2000-2030 } & \text { land use }\end{array}$

Commodities: cereals, sugar, oilseeds, horticulture, other crops, cattle, pork $\&$ poultry, dairy, processed Land use: 13 classes

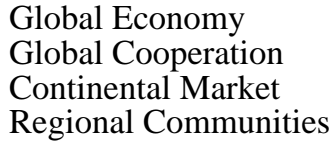

ESPON $^{\#}$ (ESPON 2007)

\author{
Scenarios for \\ European Spatial \\ Developing Planning
}
EU27
2015 and Mainly
2030 NUTS
regions

\author{
1 reference scenario \\ 20 thematic scenarios \\ 2 policy scenarios \\ 1 prescriptive scenario
}

\begin{abstract}
${ }^{\dagger}$ Advanced Terrestrial Ecosystem Analysis and Modelling; http://www.pik-potsdam.de/ateam/
* Prospective Environmental Analysis of Land Use Developments in Europe; http://www.eea.europa.eu/prelude

$\S$ Assessing Large scale Risks for biodiversity with tested Methods; http://www.alarmproject.net/alarm/

I Sustainability Impact Assessment: Tools for Environmental, Social, Economic Effects of Multifunctional

Land Use in European Regions; http://www.sensor-ip.org/

$\dagger \dagger$ Nomenclature of Territorial Units for Statistics; http://ec.europa.eu/eurostat/ramon/nuts/home regions en.html
\end{abstract}

II EURURALIS; http://www.eururalis.eu

\# European Spatial Planning Observation Network; http://www.espon.eu

example, Busch (2006) grouped 24 scenarios from six global and European studies under just four broad labels: global markets, global society, continental barriers, and regional sustainability. In addition, several studies share a common pedigree. The PRELUDE and ALARM scenarios stem from the ATEAM methods (Ewert et al. 2005, Rounsevell et al. 2005, 2006), and the CLUE model (Verburg et al. 2008, 2010) has been used in both SENSOR and the EUruralis to provide the spatial disaggregation of land use change (Table 1).

There are also signs of common reasoning in storyline interpretation to assess the scenario outcomes among European scenario studies. For example, both ATEAM (Schröter et al. 2005, Rounsevell et al. 2006) and EUruralis (WUR/MNP
2008) project significant land abandonment in unfavorable production regions when trade barriers and agricultural subsidies are abolished. Although such a future is consistent with recent observations, e.g., in European mountain regions (MacDonald et al. 2000), reductions in subsidies need not necessarily lead to wide-scale abandonment. In New Zealand, for example, radical policy reform in 1984 led to the complete abolishment of agricultural subsidies. After an initial difficult period, the sector managed to redevelop through both diversification and the reduction of inputs in marginal regions, with the result that little land was abandoned (Smith and Montgomery 2004, MacLeod and Moller 2006).

The objective of any explorative scenario exercise is to assess the variation in possible futures to 
Table 2. Definitions of the most important scenario terminology used in this paper.

\begin{tabular}{ll}
\hline \hline Scenario term & Definition \\
\hline Driver & Any natural or human-induced factor that directly or indirectly causes a change. \\
$\begin{array}{l}\text { Scenario } \\
\text { assumptions }\end{array}$ & $\begin{array}{l}\text { A coherent and internally consistent set of principles about key drivers and relationships, which can } \\
\text { consist of both narrative storylines and trends of key drivers. }\end{array}$ \\
$\begin{array}{l}\text { Scenario logic } \\
\text { The conceptual framework to structure alternative scenarios based on the most important and uncertain } \\
\text { drivers. }\end{array}$ \\
$\begin{array}{l}\text { Scenario } \\
\text { (outcome) }\end{array}$ & $\begin{array}{l}\text { A plausible image of the future, based on the qualitative or quantitative interpretation of a set of } \\
\text { scenario assumptions, which can be presented as narrative storylines or quantitative figures and maps. }\end{array}$ \\
Storyline & $\begin{array}{l}\text { A qualitative description of the future that can be used to describe both scenario assumptions and } \\
\text { scenario outcomes. Storylines are often narratives but could also be images or animations. }\end{array}$ \\
\hline
\end{tabular}

provide insights into the range of potential outcomes (Alcamo 2001, Van der Heijden 2005, Zurek and Henrichs 2007, Rounsevell and Metzger 2010). These results provide stakeholders with guidance for policy development, planning, and management. Generally speaking, the scenario logic is used to ensure sufficient coverage of variation in future developments. However, outcomes are also influenced by differences in storyline interpretation and quantitative modeling assumptions. Variation in outcomes is reduced by common paradigms, as illustrated for land abandonment, whereas alternative modeling methods can enhance variation. Busch (2006) has shown that, for similar narrative scenarios, global models have contrasting outcomes for Europe compared with Europeanscale studies.

The convergence of European scenarios is an undesirable development because it ultimately limits the range of possible outcomes that can be explored and may not reflect the full diversity of plausible futures. This is especially important when investigating alternative policy directions, each of which can have multiple outcomes depending on the uptake or success of the policy. For example, this is the case for rural regions, given likely changes in policies for rural development, including the Common Agricultural Policy (CAP). The consequences for people living and working in rural regions depend on complex and dynamic processes that are determined by a range of driving forces, including demographic, socioeconomic, technological, and environmental change. This implies that for rural scenario studies, it is important to interpret the future outcomes of alternative policy directions, which rely heavily on personal judgment. Set paradigms must be avoided and personal judgments of the outcomes of different policy directions should be made explicit to provide stakeholders with transparent information to evaluate suitable policy options (De Vries and Petersen 2009).

Here, we present a novel concept in scenario development to explicitly address and analyze judgment in scenario development. Using a set of scenarios for the future of European rural regions as an example, we explore how alternative worldviews influence the interpretation of scenario outcomes. Although our study is based on qualitative reasoning, we discuss the implications of this approach for quantitative modeling.

\section{EXPLORING PERSONAL JUDGMENT IN RURAL DEVELOPMENT SCENARIOS}

\section{Developing scenarios for rural Europe}

As part of the Foresight Analysis of Rural Areas Of Europe (FARO-EU) project for the European Commission, we developed contrasting scenarios for the future of European rural regions. The development involved two stakeholder workshops with approximately 15 EU policy makers from Directorate General (DG) Agriculture and DG 
Regio and a few national policy makers seconded to Brussels. During the first workshop we asked the policy makers to individually score the importance of a range of drivers and policy issues that could affect rural regions. The outcomes of this consultation were then discussed in plenary. In addition, we presented the policy makers with a number of scenarios and asked them to discuss each scenario's relevance for the FARO-EU project (Table 3). During a second workshop we presented the policy makers with initial results, and asked for specific feedback and comments, which were used to improve the scenarios.

Although business management textbooks discuss scenario methods (e.g., Van der Heijden 2005), explicit descriptions of the methods are surprisingly rare in the scientific literature and can lead to confusion, especially when concepts are also poorly defined. We summarize the scenario development as following five stages (Fig. 1) that are consistent with the terms defined by us (Table 2).

Stage 1 was to define the focal question and spatial boundaries. These were defined by the project aims: to explore the future of European rural regions, focusing specifically on working and living conditions. The time frame of the project was determined after the first policy workshop. Although the policy makers thought that climate change could have serious effects in rural regions, they felt that a time frame greater than 25 years would have limited policy relevance. It was therefore decided to focus on 2030. We then used the results from the policy workshop to construct a list of relevant drivers, which was Stage 2. Relevant drivers were identified for the society, technology, economy, environment and policy/governance (STEEP) categories, but we decided to exclude environment and society drivers. Although these categories could influence working and living conditions in rural regions, we see them as scenario outcomes, rather than drivers that can be described in the scenario assumptions.

The stakeholders identified the future of the CAP after 2013 as one of the most important and uncertain factors influencing future working and living conditions in European rural areas. However, the project did not envisage the ex ante evaluation of specific policy reforms (cf. Van Ittersum et al. 2008), but rather explored the consequences of broad policy directions. In Stage 3, we therefore structured our scenarios on two different worldviews. The first is a world based on a strong belief that the public sector must intervene to solve social, economic, and environmental problems to achieve social, economic, and territorial equity and environmental protection. This we label the Muskateers 'all for one and one for all' scenario. The second world vision is a world in which there is a strong belief that market liberalization will achieve solutions to social, economic, and environmental problems by strengthening competitiveness in the global economy. This we label Marketeer scenario.

In Stage 4, the narrative storylines for the Muskateer and Marketeer scenario assumptions were developed for the future trends in policy, governance, economy, and technology (Table 3). These storylines were then used to explore the trends of the important drivers affecting change (Table 4; cf. Nakicenovic et al. 2000, Rounsevell et al. 2006).

Following traditional scenario methods (Rounsevell et al. 2006, Zurek and Henrichs 2007), the trends in the drivers (Table 4) are used in Stage 5 to make projections for specific indicators related to rural development, either qualitatively (cf. MA 2005) or using quantitative numerical models (cf. Rounsevell et al. 2006). However, it is difficult to define consistent rules to assess the consequences of alternative narratives objectively without reflecting political ideologies or personal beliefs. For example, as illustrated in the introduction, there are alternative plausible hypotheses about the consequences of abolishing agricultural subsidies. Similar contrasting outcomes can be devised for employment, social cohesion, and the environment, all based on valid but contrasting underlying assumptions imbedded in personal beliefs or worldviews.

These discussions led us to construct a framework for making explicit personal judgments of scenario implications, allowing us to explore its potential influence on future outcomes.

\section{Assessing personal judgment in scenario outcomes}

A consistent analysis of personal judgment in scenario outcomes (Stage 5 in Fig. 1) becomes possible when the scenario assumptions are interpreted from contrasting perspectives. A supporter of the worldview has high expectations 
Table 3. Scenario principles for alternative plausible changes affecting European rural regions.

General principles

- There is a strong belief that the public sector must intervene to solve social, economic, and environmental problems.

- The main aims of public intervention are socialeconomic equity, territorial equity, and environmental protection.

- Subsidies, tariffs, public investment, and regulation are important instruments to achieve these aims, and are paid for by society.

Policy

- EU and national policies focus on supporting the Sustainable Development Strategy (EC 2009), focusing on the synergy between economic, social, and environmental goals.

- Policies aim for integrated development at a regional scale.

- Special attention is given to supporting economically and socially marginal areas, and ecologically valuable areas.

- The EU continues to protect vulnerable agricultural sectors from the global market. When appropriate, income support is replaced by a system of targeted payments to farmers and other landowners for their contribution to the improvement of public goods.

- Multifunctionality of rural areas is supported by public investment (e.g., in infrastructure and information and communication technology [ICT]) and by providing policies that aim to make living in rural areas affordable for all.

- Environmental protection is tackled through regulation and public investment.

- Designated sites or regions receive strong protection.

- Policy intervention aims to reduce landscape fragmentation and urban sprawl.

- There are political initiatives to stimulate sustainable use of resources and to prevent or adapt to environmental impacts, e.g., forest fires, droughts, flooding etc.
- There is a strong belief that market liberalization will achieve solutions to social, economic, and environmental problems.

- The main aim of market liberalization is to strengthen competitiveness in the global economy to protect socioeconomic achievements.

- Low taxation, light bureaucracy, market flexibility, and deregulation are important instruments to achieve these aims.

- EU and national policies are based on the economic dimensions of the Lisbon strategy (EC 2004) and the aim of Europe leading the world economy.

- Policy intervention is limited and aims to strengthen European competitiveness.

- Special attention is given to leading economic regions.

- The EU abolishes export subsidies, import tariffs, domestic subsidies, milk and sugar quotas, and cohesion policies.

- The only important policies focus on investment in $\mathrm{R} \& \mathrm{D}$, technology and the knowledge economy.

- Environmental protection depends on market mechanisms and the willingness to pay principle.

- Designated sites or regions receive moderate protection.

- There is little intervention through spatial land use planning.

- Market mechanisms are applied to the effective use of resources and to help to prevent or adapt to environmental effects, e.g., forest fires, droughts, flooding etc. 
- The EU implements climate change mitigation policies, but outcomes are marginal by 2030 because of the inertia in the climate system.
- The EU does not implement climate change mitigation policies.

Governance

- The EU devolves political and financial responsibility to the regions (the subsidiarity principle).

- Rural development is governed by local authorities that fund public participation and bottom-up initiatives.
- Government is centralized and follows the principle of nonintervention by privatizing national assets. Intervention only occurs in situations where the market fails.

- Rural development is steered by market forces.

Economy

- Public investment is used to underpin sustainable development and regional self-sufficiency.

- The EU budget is significantly increased as a proportion of GDP. The additional resources are used to support cohesion policy and payments to farmers for the provision of public goods both of which discriminate strongly in favor of poorer areas and social groups.
- Public investment is minimized and consequently taxation is reduced.

- Private investment is concentrated in the areas with the greatest comparative advantage and this leads to regional specialization in a global market place.

Technology

- There is substantial public investment in R\&D and infrastructure including ICT. There is major investment in ICT infrastructure in rural areas providing new business opportunities and improving accessibility.

- There is moderate investment in agricultural productivity.
- Technological development is driven by market-led, private investment in regions with sufficient demand.

- There will be considerable investment in agricultural productivity, especially in regions with a comparative advantage. of positive outcomes, which we refer to as a highexpectation world (HEW). Policies, societal trends, and markets work out as expected and the social values of its supporters are not compromised. A detractor of the worldview believes that the assumed positive outcomes will not be realized, resulting in a low-expectation world (LEW). The societal and economic developments, which are expected by the supporter, do not work out. Furthermore, there are "forgotten" trade-offs of a HEW, which compromise the detractor's social values. For example, the pursuit of economic growth may lead to environmental degradation, which may not be of great concern to a Marketeer but be perceived as a negative trade-off by others.

Although a HEW and LEW interpretation of the Muskateer and Marketeer scenario principles could be achieved through stakeholder consultation, we made our interpretation based on the insights we obtained in the two policy workshops and our expert knowledge. We illustrate the extent to which personal judgment could influence scenario outcomes (Table 5). For example, in a Muskateer HEW, strong governments lead to desired levels of public services in rural regions, whereas in a LEW, bureaucracy overwhelms efficient government and regions exploit incoherent policies to their own benefit. In the Marketeer HEW a lean government allows a regional governance structure to emerge to support public service provision on a demand basis, whereas under a LEW, peripheral and poor regions are disadvantaged and have little political influence, resulting in inadequate service provision. The complete results of this qualitative assessment are illustrated for policy, governance, economic, 
Fig. 1. Five common stages of scenario development, based on the eight steps defined by Schwartz (1998).

\title{
Stages in scenario development
}

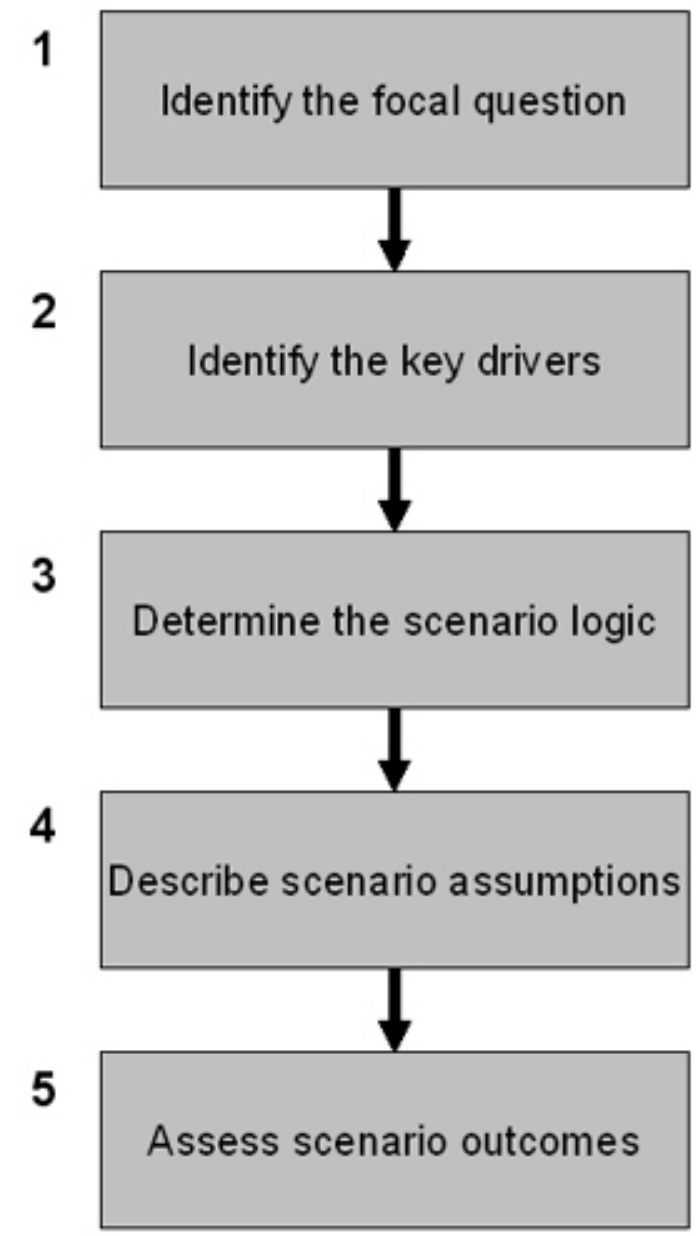

Identify the aims of the scenario exercise and define spatial and temporal system boundaries.

\begin{abstract}
Identify the drivers that affect the focal question, both directly and indirectly, and determine the most important and uncertain drivers.
\end{abstract}

Define the framework within which the scenario assumptions are developed, based on the most important drivers.

\begin{abstract}
Describe the principles and assumptions for the alternative futures using qualitative storylines and trends of the most important drivers.
\end{abstract}

Assess the implications or potential impacts of the scenario assumptions, either using qualitative storylines and images, or by developing quantitative scenarios based on numerical models.

technology, societal, and environmental outcomes (Table 5).

The difference between HEW and LEW outcomes defines the judgment-related variation for each scenario, which we term the belief range. When traditional scenarios have single outcomes that are easily compared, belief ranges can show partial or complete overlap (Fig. 2). Although this may seem complex compared to traditional explorative storylines with just one interpretation for each scenario, we argue that such results reflect political reality on discussions of policy direction outcomes. Furthermore, belief ranges provide valuable insights into personal perceptions and thus form a useful extension to existing scenario methods.

Despite the fact that our analysis is based on mental models of potential outcomes, applying a consistent logic helps to explore the extent to which personal 
Table 4. Trends of principal drivers affecting working and living in European rural regions under two contrasting scenarios.

\begin{tabular}{|c|c|c|c|c|}
\hline $\begin{array}{l}\text { Categories of } \\
\text { drivers }\end{array}$ & Indirect driver & Direct driver & Muskateer Trend & Marketeer Trend \\
\hline \multicolumn{5}{|l|}{ Policy } \\
\hline \multirow[t]{5}{*}{ International policy } & influence of the WTO & $\begin{array}{l}\text { subsidies, market } \\
\text { intervention }\end{array}$ & $\begin{array}{c}\downarrow \text { no EU support } \\
\text { of WTO }\end{array}$ & $\begin{array}{c}\uparrow \text { strong EU support } \\
\text { of WTO }\end{array}$ \\
\hline & $\begin{array}{l}\text { agricultural production } \\
\text { policies }\end{array}$ & subsidies, tariffs, quota & $\rightarrow \quad$ no change & abolished \\
\hline & rural development & $\begin{array}{l}\text { subsidies, restrictions, } \\
\text { market intervention }\end{array}$ & $\uparrow \quad$ increased & abolished \\
\hline & environmental policy & $\begin{array}{l}\text { subsidies, restrictions, } \\
\text { market intervention }\end{array}$ & $\uparrow$ strengthened & weakened \\
\hline & cohesion policy & investment & $\uparrow \quad$ increased & abolished \\
\hline $\begin{array}{l}\text { National and } \\
\text { regional policies }\end{array}$ & $\begin{array}{l}\text { policies for transport, } \\
\text { education, health, ICT }\end{array}$ & $\begin{array}{l}\text { subsidies, investment, } \\
\text { restrictions }\end{array}$ & $\uparrow \quad$ increase & $\downarrow \quad$ less important \\
\hline
\end{tabular}

Governance

$\begin{array}{llllll}\begin{array}{l}\text { strength of subnational } \\ \text { government }\end{array} & \text { regional infrastructure } & \uparrow & \text { expanded } & \rightarrow & \text { little expansion } \\ \text { rural support structures } & \text { rural services } & \uparrow & \text { expanded } & \uparrow & \text { little expansion } \\ & \text { political centralization } & \downarrow & \text { decrease } & \uparrow & \text { increase }\end{array}$

Economy

Global economy $\quad$ economic development $\quad$ demand $\quad \rightarrow \quad \begin{gathered}\text { stable GDP } \\ \text { growth }\end{gathered}$ rapid GDP growth

Technology

Technological development

Investment in infrastructure
R\&D spending

infrastructure and knowledge economies yield and profit

access (transport, energy, $\quad \uparrow$ ICT, knowledge) $\uparrow$ slow increase $\uparrow$ great increase

uniform $\quad \uparrow$ increase in certain increase regions

$\uparrow=$ increasing trend, $\rightarrow=$ stable trend, $\downarrow=$ decreasing trend.

ICT $=$ Information and communication technologies 
Table 5. High expectation world (HEW) and low expectation world (LEW) interpretations of the outcomes of the scenario principles (Table 3 ).

Policy

HEW The influence of the WTO on EU policy is limited. Cohesion policies are effective and enhance the vitality of vulnerable rural regions. As a result, the competitiveness of rural regions is increased and this buffers against globalization trends.

LEW Cohesion policies do not achieve their social and economic goals because the cost of policy implementation is too high. Furthermore, global influences are more strongly felt, structures proves impossible because of public concerns. with the WTO restricting EU subsidies.
The competitiveness and comparative advantage of European regions in the world economy is greatly enhanced. The WTO has a strong influence and this further assists European trade within the global market place.

Governance

HEW Government is strong and effective leading to the desired levels of public services. Income and regional inequalities are reduced. This leads to a vibrant democracy and caring communities.

LEW Bureaucracy overwhelms efficient government and stifles innovation. Individuals and regions exploit incoherent policies for their own benefit, resulting in tensions and conflicts between regions.

Economy

HEW Policy intervention leads to the convergence of GDP between regions, resulting in a balanced spread of economic functions (demand, supply, and employment) and an expansion of the economic heart of Europe away from the London-Milan axis. Remote and intermediate rural areas are strengthened through the diversification of economic activities. In some rural areas, the primary sector remains an important part of the economy. Agricultural abandonment is reduced and rural population decline is stemmed by the creation of employment opportunities in the secondary and tertiary sectors (e.g. agri-business, services, information and communication technologies [ICT], regional tourism).

LEW The high cost of intervention and subsidies leads to high taxation, high costs (employment, transport etc.), and high product prices. This leads to a lack of competitiveness in global markets. The European economy lags behind the rest of the world, with economic activities concentrating in urban and peri-urban areas. Rural areas suffer high unemployment and low incomes leading to land abandonment and the stagnation of economic activities.

Technology

HEW Technological development is spread equally across Europe, including rural areas. Many public services are transformed and delivered locally through ICT. The accessibility of rural areas is greatly improved by public investment in infrastructure such as the transport network and ICT.

A 'lean' government allows regional governance structures to emerge to support public service provision on a demand basis.

Peripheral and poor regions are disadvantaged and have little political influence, resulting in inadequate service provision. Richer regions dictate to poorer regions.

Market led approaches and low taxation maximize economic benefits and keep prices low. Higher economic growth trickles down to the benefit of society as a whole, including rural regions of Europe. The adjustment to lower production costs in marginal regions increases the competitiveness of agriculture and as a consequence there is very little land abandonment. Regions diversify agricultural and other activities in line with their comparative advantages. Farmers either diversify or specialize their business activities in response to their exposure to the global market place. Tourism in peripheral regions benefits from the greater mobility of richer people

A lack of public investment leads to social and economic inequality between regions and between cities and rural areas. A large fraction of the food demand is met by imports resulting in the relocation of agricultural production to other parts of the world. Consequently, marginal agricultural land is abandoned and rural unemployment is high. Agricultural production intensifies in optimal areas.

The rate of technological development is high because of the success of private enterprise. Society at large benefits from rapid technology transfer through market mechanisms. 
LEW Low technological development arises from a lack of appropriate targeting (not market-led) of public expenditure. Technology transfer is low and innovation is stifled by the burden of bureaucracy.
Because of short term thinking, the market does not adequately deliver technological innovation. The developments that do occur are not available to everyone. Investment in technology is concentrated in regions with a comparative advantage.

Society

HEW Social values lead to local communities with strong cohesion. There is an increased demand for regional goods and services and agricultural land abandonment is low because society is willing to pay a higher price for high quality, local food. Farmers receive subsidies to provide landscape services and environmental protection, leading to an attractive countryside. Rural areas are a popular place to live and agricultural abandonment is reduced.

LEW Free-riders, benefiting from society while seeking maximum personal gain, cause tensions in society. Although education levels are uniform, there are few centers of excellence, and European social development lags behind other parts of the world. People resent the economic stagnation and the high prices they have to pay for food and farmers become isolated from the wider society. In some regions agricultural land is abandoned.
There is strong competition between people, companies and regions leading to a virtuous circle of investment, technological development, and wealth creation. Society as a whole benefits from the high economic growth with profits being ploughed back into health, education, and infrastructure. Rural areas flourish with enterprising individuals creating new business opportunities and employment. There is little agricultural abandonment.

There are great inequalities between regions and social groups. Income and service inequalities lead to high migration between regions. People migrate from lagging regions further reinforcing inequalities. Because young people are more mobile, ageing in rural areas is reinforced. In many regions marginal agricultural land is abandoned. This leads to an increasing gap between the haves and the have-nots causing tensions in society.

Environment

HEW Strong government regulation results in adequate adaptation measures to cope with environmental impacts, e.g., pollution, flooding, droughts, and forest fires. Environmental pollution is diffuse and relatively low due to both government regulation and more extensive agricultural production strategies. There is public investment in renewable energy to reduce carbon emissions. Biodiversity is protected and managed for its intrinsic value.

LEW In some regions, environmental effects, e.g., forest fires, droughts, flooding etc. form serious risks in spite of the political initiatives to adapt and attempts to mitigate carbon emissions. Subsidies push up the price of land and other agricultural production costs. Farmers respond by seeking to maximize outputs through increased inputs. Consequently, diffuse pollution (nitrates and pesticides) from agriculture is a major problem. Intensive production of bio-energy crops, especially in previously extensively used regions, has negative consequences for biodiversity, which continues to decline despite considerable effort.
Market-based solutions ensure adequate adaptation measures (e.g., insurance and technical innovation) to cope with negative environmental effects, e.g., pollution, flooding, droughts and forest fires. Pollution from agriculture diminishes because farmers optimize chemical inputs in an attempt to lower costs and boost profitability. There is limited investment in renewable energy because energy prices stabilize. Biodiversity is valued and managed for the services it provides to society.

In some regions, environmental issues such as forest fires, droughts, flooding etc. form serious risks in spite of the attempt to use market-based solutions to cope with environmental problems. Forest fires are a problem in the Mediterranean, where forest management policy is weak. Regions with a comparative advantage intensify agricultural production and this leads to environmental pollution problems. Rising energy prices lead to a demand for bioenergy, which competes with conventional agriculture on a global market. In strong regions the pressures caused by economic growth negatively affect biodiversity, whereas in marginal regions there is little willingness to pay for conservation because other issues are more pressing. beliefs or worldviews can influence these outcomes. Our results show that there is considerable overlap in the belief ranges for the policy interventionist Muskateer scenario and the market liberalization Marketeer scenario (cf. Fig. 2b,c,d). A further inspection of the HEW/LEW interpretations reveals that although both scenarios result in positive outcomes for the HEW, the risk of negative outcomes appears greater in the market-led scenario, because the interventionist measures provides more buffering from external pressures by investing public funds to avoid or limit negative consequences. However, more quantitative methods are required to explore the range of judgment-based variation within each scenario, as discussed below. 
Fig. 2. The difference between high-expectation world (HEW) and low-expectation world (LEW) scenario outcomes for a given indicator, $i$, define the belief range. Conceptual graphs illustrate possible belief ranges for two alternative scenarios X and Y. Although belief ranges do not necessarily overlap (a), partial (b) or complete (c,d) overlap are possible.
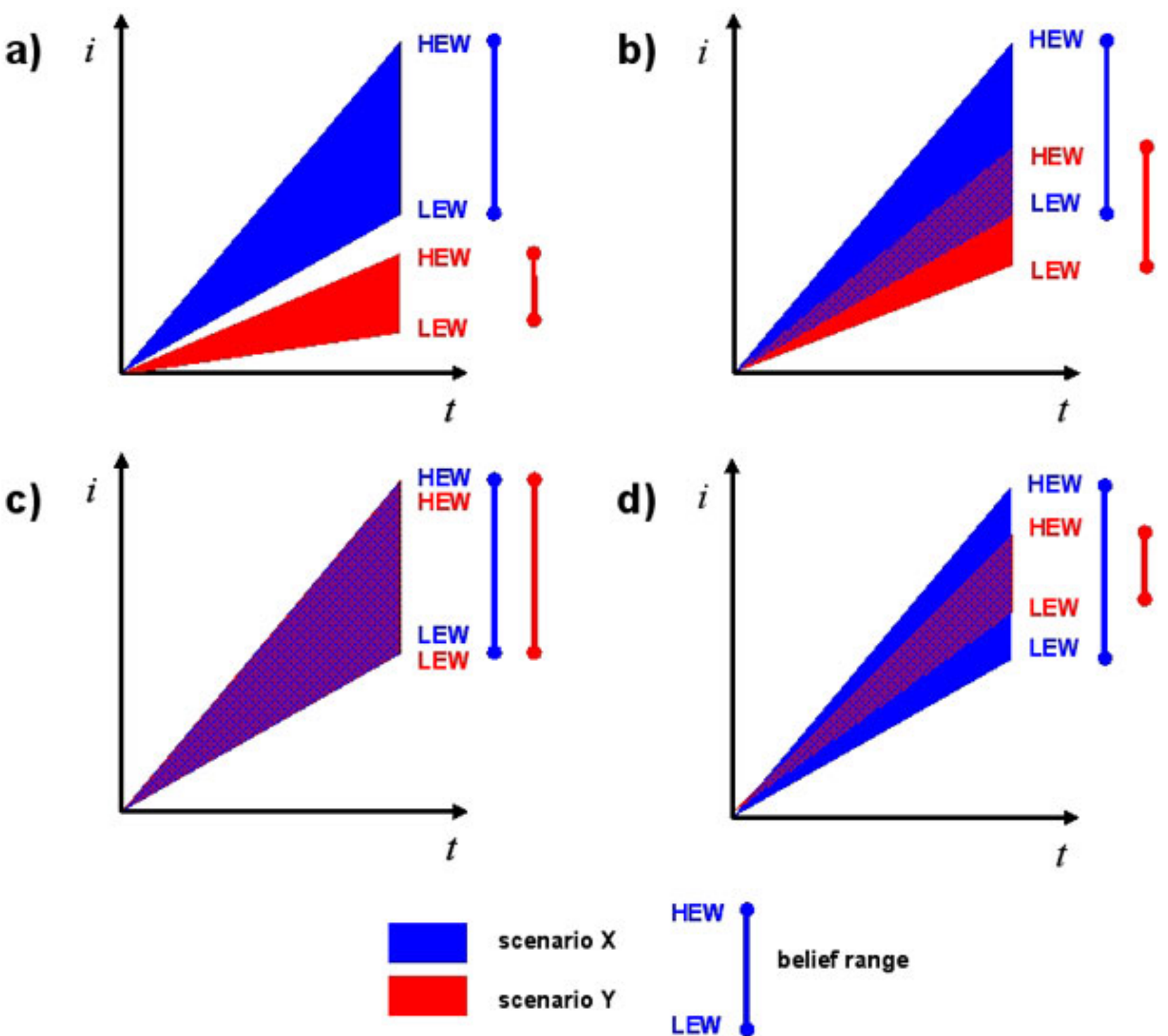

belief range 


\section{DISCUSSION}

Over recent decades, conventional scenario methods have been used extensively to explore future effects on climate, ecosystems, and the services they provide (e.g., MA 2005, Schröter et al. 2005, IPCC 2007). Scenarios have proved to be successful in linking qualitative storylines to quantitative models, providing numeric outcomes for potential effects on ecology and society. When the processes that are influenced by the storylines are well understood and can be adequately quantified, as with many biophysical and macroeconomic processes, traditional methods for interpreting scenario outcomes (Stage 5) work well. However, when processes are less well understood, as is the case in many social processes, interpretation and judgment become more important.

The exercise presented here illustrates how personal judgment can influence scenario outcomes. There is a risk of developing fixed paradigms in scenario development that ignore other possible outcomes within the same storyline framework. This is an important observation that, as far as we are aware, has not yet received attention in the scenario literature. Although ex ante policy impact assessment tools (cf. Van Ittersum et al. 2008) are useful for exploring short-term effects of specific policy measures, explorative scenarios should span a wide range of possible future outcomes to explore medium to long-term effects on social-ecological systems. Paradigms based on one interpretation of a scenario create an artificial and undesirable limit on the range of future worlds explored.

At first, it may seem confusing that alternative scenario directions can result in similar outcomes (cf. Fig. 2b,c,d). Our example shows that both policy intervention and market liberalization can result in positive or negative implications for rural regions. However, the mechanisms leading to these outcomes are different among scenarios. The HEW/ LEW concept forms a useful first step to tease out these different processes. For example, in the Muskateer HEW there is large public investment in rural infrastructure, allowing public services to be transformed and delivered through better transport networks and information and communication technologies, resulting in improved accessibility for businesses. Conversely, in the Marketeer HEW, technological development is high because of the success of private enterprise, and rural society benefits from rapid technology transfer through market mechanisms. Such an analysis can lead to further research to identify and quantify thresholds for the success of both mechanisms.

It is a considerable challenge for the environmental change modeling community to develop tools that allow judgment to be made explicit. Ideally, the HEW/LEW concept could be translated into transparent quantitative models incorporating the range of processes that could operate within the same scenario. Such models could be informed by open discussions with stakeholders and subsequently explore the belief range for each scenario (cf. Fig. 2). However, existing numerical models (e.g., MNP 2006, Rounsevell et al. 2006, Verboom et al. 2007, Verburg et al. 2010) are programmed to follow predefined scenario interpretations of key drivers and cannot be easily adapted for this purpose. Developing tools that can incorporate judgment will therefore form a considerable challenge for the modeling community, requiring considerable research investment.

\section{CONCLUSIONS}

Personal judgment and interpretation can greatly influence scenario outcomes and can even lead to the development of scenario paradigms that limit the range of uncertainty that is covered by the scenarios. It is of great importance to make these judgments explicit in scenario development, especially when exploring broad consequences of alternative policy directions that may be based in political worldviews. The HEW/LEW concept outlined here provides a transparent framework for identifying and understanding differences in outcomes based on personal judgment. In addition, it helps to tease out underlying processes that can lead to these alternative outcomes. The ultimate challenge will be to develop flexible quantitative modeling techniques that are able to quantify judgment-related variation for alternative scenarios by incorporating multiple processes within the same scenario.

Responses to this article can be read online at:

http://www.ecologyandsociety.org/voll5/iss2/art5/responses/ 


\section{Acknowledgments:}

The work presented here was carried out as part of the European Union funded Framework Programme 6 Specific Targeted Research Project FARO-EU (Foresight Analysis for Rural Regions of Europe, contract 044495).

\section{LITERATURE CITED}

Alcamo, J. 2001. Scenarios as toolfor international environmental assessments. Environmental Issue Report Number 24. European Environment Agency, Copenhagen, Denmark.

Busch, G. 2006. Future European agricultural landscapes -What can we learn from existing quantitative land use scenario studies? Agriculture, Ecosystems \& Environment 114:121-140.

De Vries, J. M., and A. C. Petersen. 2009. Conceptualizing sustainable development. An assessment methodology connecting values, knowledge, worldviews and scenarios. Ecological Economics 68:1006-1019.

European Communities (EC). 2004. Facing the challenge, the Lisbon Strategy for growth and employment. Commission of the European Communities, Brussels, Belgium. [online] URL:

http://ec.europa.eu/growthandjobs/pdf/kok report en. pdf.

European Communities (EC). 2009. Mainstreaming sustainable development into EU policies: 2009 review of the European Union Strategy for Sustainable Development. Commission of the European Communities, Brussels, Belgium. [online] URL: http://eur-lex.europa.eu/LexUriServ/ LexUriServ.do?uri=COM:2009:0400:FIN:EN:PDF

European Environment Agency (EEA). 2007 Land-use scenarios for Europe: qualitative and quantitative analysis on a European scale. EEA Technical Report 09/2007. European Environment Agency, Copenhagen, Denmark.
European Spatial Planning Observation Network (ESPON). 2007. Scenarios on the territorial future of Europe. Report of ESPON Project 3.2. [online] URL: http://www.espon.eu/export/sites/default/ Documents/Publications/ESPON2006Publications/ SpatialScenarios/espon3.2 60p. final 16-7-2007-c. pdf.

Ewert, F., M. D. A. Rounsevell, I. Reginster, M. J. Metzger, and R. Leemans. 2005. Future scenarios of European agricultural land use. I. Estimating changes in crop productivity. Agriculture, Ecosystems \& Environment 107:101-116.

Helming, K., M. Pérez-Soba, and P. Tabbusch. 2008. Sustainability impact assessment of land use changes. Springer, Berlin, Germany.

Intergovernmental Panel on Climate Change (IPCC). 2007. Summary for policymakers. Pages 7-22 in M. L. Parry, O. F. Canziani, J. P. Palutikof, P. J. van der Linden, and C. E. Hanson, editors. Climate change 2007: impacts, adaptation and vulnerability. Cambridge University Press, Cambridge, UK.

Kuhlman, T. 2008. Scenarios: driving forces and policies. Pages 131-157 in K. Helming, M. PérezSoba, and P. Tabbusch, editors. Sustainability impact assessment of land use changes. Springer, Berlin, Germany.

Millennium Ecosystem Assessment (MA). 2005. Millennium ecosystem assessment synthesis report. Island Press, Washington, D.C., USA.

MacDonald, D., J. R. Crabtree, G. Wiesinger, T. Dax, N. Stamou, P. Fleury, J. Gutierrez Lazpita, and A. Gibon. 2000. Agricultural abandonment in mountain areas of Europe: environmental consequences and policy response. Journal of Environmental Management 59:47-69.

MacLeod, C., and H. Moller. 2006. Intensification and diversification of New Zealand agriculture since 1960: an evaluation of current indicators of land use change. Agriculture Ecosystems \& Environment 115: 201-218.

The Netherlands Environmental Assessment Agency (MNP). 2006. Integrated modeling of global environmental change. An overview of 
IMAGE 2.4. Environmental Assessment Agency Report Number 500110002. Bilthoven, The Netherlands.

Nakicenovic, N., J. Alcamo, G. Davis, B. de Vries, J. Fenhann, S. Gaffin, K. Gregory, A. Grübler, T. Y. Jung, T. Kram, E. la Rovere, L. Michaelis, S. Mori, T. Morita, W. Pepper, H. Pitcher, L. Price, K. Riahi, A. Roehrl, H.-H. Rogner, A. Sankovski, M. E. Schlesinger, P. R. Shukla, S. Smith, R. J. Swart, S. van Rooijen, N. Victor, and Z. Dadi. 2000. Special report on emissions scenarios. Cambridge University Press, Cambridge, UK.

Rashkin, P. D. 2005. Global scenarios: background review for the Millennium Ecosystem Assessment. Ecosystems 8:133-142.

Rounsevell, M. D. A., F. Ewert, I. Reginster, R. Leemans, and T. R. Carter. 2005. Future scenarios of European agricultural land use. II. Projecting changes in cropland and grassland. Agriculture Ecosystems \& Environment 107:117-135.

Rounsevell, M. D. A., and M. J. Metzger. 2010. Developing qualitative scenarios and storylines for environmental change assessment. Wiley Interdisciplinary Reviews: Climate Change, in press.

Rounsevell, M. D. A., I. Reginster, M. B. Araújo, T. R. Carter, N. Dendoncker, F. Ewert, J. I. House, S. Kankaanpää, R. Leemans, M. J. Metzger, C. Schmit, P. Smith, and G. Tuck. 2006. A coherent set of future land use change scenarios for Europe. Agriculture Ecosystems \& Environment 114:57-68.

Schröter, D., W. Cramer, R. Leemans, I. C. Prentice, M. B. Araújo, N. W. Arnell,A. Bondeau, H. Bugmann, T. R. Carter, C. A. Garcia, A. C. de la Vega-Leinert, M. Erhard, F. Ewert, M. Glendining, J. I. House, S. Kankaanpää, R. J. T. Klein, S. Lavorel, M. Lindner, M. J. Metzger, J. Meyer, T. D. Mitchell, I. Reginster, M. Rounsevell, S. Sabaté, S. Sitch, B. Smith, J. Smith, P. Smith, M. T. Sykes, K. Thonicke, W. Thuiller, G. Tuck, S. Zaehle, and B. Zierl. 2005. Ecosystem service supply and human vulnerability to global change in Europe. Science 310:1333-1337.
Schwartz, P. 1998. The art of the long view: planning for the future in an uncertain world. Wiley, Chichester, UK.

Settele, J., V. Hammen, P. Hulme, U. Karlson, S. Klotz, M. Kotarac, W. Kunin, G. Marion, M. O'Connor, T. Petanidou, K. Peterson, S. Potts, H. Pritchard, P. Pysek, M. Rounsevell, J. Spangenberg, I. Steffan-Dewenter, M. Sykes, M. Vighi, M. Zobel, and I. Kühn. 2005. ALARM: Assessing LArge-scale environmental Risks for biodiversity with tested Methods. Gaia Perspectives in Science, Humanities and Economics 14:69-72.

Smith, W. and H. Montgomery. 2004. Revolution or evolution? New Zealand agriculture since 1984. GeoJournal 59:107-118.

Van der Heijden, K. 2005. Scenarios: the art of strategic conversation. Second Edition. Wiley, Chichester, UK.

Van Ittersum, M. K., F. Ewert, T. Heckelei, J. Wery, J. A. Olsson, E. Andersen, I. Bezlepkina, F. Brouwer, M. Donatelli, G. Flinchman, L. Olsson, A. Rizzoli, T. van der Wal, J. E. Wien, and J. Wolf. 2008. Integrated assessment of agricultural systems - a component-based framework for the European Union (SEAMLESS). Agricultural Systems 96:150-165.

Verboom, J., L. R. M. Alkemade, J. Klijn, M. J. Metzger, and R. Reijnen. 2007. Combining biodiversity modeling with political and economic development scenarios for 25 EU countries. Ecological Economics 62:267-276.

Verburg, P. H., B. Eickhout, and H. van Meijl. 2008. A multi-scale, multi-model approach for analyzing the future dynamics of European land use. Annals of Regional Science 42:57-77.

Verburg, P. H., D. B. van Berkel, A. M. van Doorn, M. van Eupen, and H.A.R.M. van den Heiligenberg. 2010. Trajectories of land use change in Europe: a model-based exploration of rural futures. Landscape Ecology 24(2):217-232.

Wageningen University and Research Centre and the Netherlands Environmental Assessment 
Agency (WUR/MNP). 2008. EURURALIS2.0

CdROM. Wageningen University and Research Centre and the Netherlands Environmental Assessment Agency, Wageningen, The Netherlands.

Zurek, M. B., and T. Henrichs. 2007. Linking scenarios across scales in international environmental scenarios. Technological Forecasting and Social Change 74:1282-1295. 